\title{
Will the American Rescue Plan Overcome Opposition to Medicaid Expansion?
}

\author{
Patrick N. O'Mahen, PhD ${ }^{1,2}$ (1) and Laura A. Petersen, MD MPH \\ ${ }^{1}$ The Center for Innovations in Quality, Effectiveness and Safety (IQUESt) at the Michael E. DeBakey VA Medical Center, Houston, TX, USA; \\ ${ }^{2}$ Section of Health Services Research, Department of Medicine, Baylor College of Medicine, Houston, TX, USA.
}

$\mathrm{J}$ Gen Intern Med 36(11):3550-2

DOI: $10.1007 / \mathrm{s} 11606-021-07084-\mathrm{x}$

(1) This is a U.S. government work and not under copyright protection in the

U.S.; foreign copyright protection may apply 2021

I March 2021, President Joseph Biden signed into law the American Rescue Plan Act (ARPA), providing \$1.9 trillion to combat the COVID-19 pandemic. ARPA broadens numerous Affordable Care Act (ACA) policies extending health insurance to the uninsured. ${ }^{1}$ These reforms include generous financial incentives for states to accept the ACA's Medicaid expansion. However, because the primary opposition to Medicaid expansion in holdout states is ideological and not economic, the effectiveness of these incentives in coaxing more states to expand is likely to be limited.

In the ACA Medicaid expansion, the federal government pays for $90 \%$ of costs for the Medicaid expansion population, which consists of adults in households with incomes under $138 \%$ of the Federal Poverty Line (FPL). States cover the remaining $10 \%$. ARPA sweetens the deal considerably for the 12 states that have not expanded. For the first 2 years of expansion, starting in Fiscal Year (FY) 2022, newly expanding states would get an increase of 5 percentage points in federal matching dollars for all legacy Medicaid programs. These legacy programs - which cover children, pregnant women, the elderly, disabled, and some parents-make up $79 \%$ of total Medicaid costs in states that have expanded. As a result, ARPA's temporary funding boost will more than offset state costs for insuring the expansion population and create large windfalls for any holdout states that choose to take expansion. According to estimates calculated by the Henry J. Kaiser Family Foundation, these windfalls would be quite large for all 12: Texas alone would net more than $\$ 1.9$ billion across FY 2022 and 2023, with three other states reaping more than $\$ 1$ billion. $^{2}$ Given evidence that taking expansion reduces net state cost spending, it seems likely that this new policy would result in fiscal gains for most states expanding under ARPA's new terms. ${ }^{3}$

Received June 3, 2021

Accepted July 21, 2021

Published online August 11, 2021
But financial incentives are not a surefire incentive to get states to expand. The ACA's current $90 \%$ federal match is exceedingly generous compared to traditional Medicaid matching rates, yet 12 states have not accepted expansion. Even widely popular optional reforms that extended Medicaid to more groups of infants, children, and pregnant women in the 1980 s were taken up by fewer than 50 states-holdouts had to be induced by federal mandates. ${ }^{4}$

Currently, resistance to expansion in holdout states comes from opponents within the Republican Party. Based on updated data originally presented by O'Mahen and Petersen ${ }^{5}$, in a given year between 2013 and 2020 every state with unified Democratic control (Democrats in control of both the governorship and the legislature) expanded Medicaid when given the opportunity. In contrast, states with divided control had a $35 \%$ chance of expanding, while Republican-controlled states had an $8 \%$ chance. However, this opposition is not merely partisan, but ideological. In Republican-controlled states where traditional business elites held sway in the Republican Party, like Michigan in 2013, enough Republicans backed expansion to push it through skeptical legislatures. In other states like Florida and Tennessee, ideological groups like Americans for Prosperity were successful in pressuring Republican legislators to oppose expansion after some Republicans initially took tentative steps toward accepting it. ${ }^{6}$ Ideological warriors have been especially effective in preventing expansion in states with many veto points that can block policy change. ${ }^{5,7}$

Overcoming ideological opposition requires political remedies, not economic ones. Five potential avenues exist. The first two political remedies are electoral, and the other three involve deploying federal power to negotiate with or pre-empt states refusing to expand. Table 1 outlines each remedy and identifies the states that have successfully used it to defuse or defeat ideological opposition.

Remedy 1: Elect Pro-expansion Politicians. Ideologues blocking Medicaid expansion are elected officials who answer to voters. Electing governors and state legislative majorities friendly to Medicaid expansion will neuter opposition. In Maine, Republican Governor Paul LePage vetoed multiple attempts to expand Medicaid. In 2018, voters replaced him with Democrat Janet Mills, who greenlighted expansion within a week of taking office in $2019 .^{8}$ In Louisiana, Democrat John Bel Edwards expanded Medicaid in his first act in office 
Table 1 Potential Political Remedies to Overcome Opposition to Medicaid Expansion

\begin{tabular}{|c|c|c|}
\hline Remedy & Type & States using remedy \\
\hline $\begin{array}{l}\text { Electing state officials } \\
\text { favoring Medicaid expansion, } \\
\text { replacing opponents }\end{array}$ & Electoral & $\begin{array}{l}\text { Pennsylvania } \\
\text { Alaska } \\
\text { Louisiana } \\
\text { Virginia } \\
\text { Maine* }\end{array}$ \\
\hline $\begin{array}{l}\text { Pass ballot initiative for } \\
\text { Medicaid expansion } \dagger\end{array}$ & Electoral & $\begin{array}{l}\text { Maine* } \\
\text { Idaho } \\
\text { Utah } \\
\text { Nebraska } \\
\text { Oklahoma } \\
\text { Missourit }\end{array}$ \\
\hline $\begin{array}{l}\text { Negotiating Section } 1115 \\
\text { waiver to accept modified } \\
\text { expansion }\end{array}$ & Federal & $\begin{array}{l}\text { Arkansas } \\
\text { Iowa } \\
\text { Michigan } \\
\text { New Hampshire } \\
\text { Montana } \\
\text { Indiana }\end{array}$ \\
\hline $\begin{array}{l}\text { Federal pre-emption of } \\
\text { Medicaid programs }\end{array}$ & Federal & $\begin{array}{l}\text { None (at least partially } \\
\text { foreclosed by NFIB } v \\
\text { Sebelius) }\end{array}$ \\
\hline $\begin{array}{l}\text { Federal legislation creating } \\
\text { national backstop to } \\
\text { expansion }\end{array}$ & Federal & $\begin{array}{l}\text { None (potential for future } \\
\text { legislation) }\end{array}$ \\
\hline
\end{tabular}

* Maine passed a ballot initiative supporting expansion in November 2017; however, it was not implemented until incoming Governor Janet Mills took office in January 2019. FFour of the 12 holdout states have provisions allowing for passage of Medicaid expansion (Florida, Mississippi, South Dakota, and Wyoming). tMissouri passed a ballot initiative mandating Medicaid expansion in August 2020, but as of July 2021, the legislature has not funded the expansion

after voters replaced Republican expansion foe Bobby Jindal in 2015. ${ }^{9}$ Finally, large Democratic gains in the Virginia state legislature made it possible for the state to approve Medicaid expansion in 2018. ${ }^{10}$

Remedy 2: Direct Democracy. The other electoral possibility to outflank ideologues blocking power is using direct democracy. Blocked in their push for Medicaid expansion by reliably re-elected large legislative majorities of conservative Republicans, activists in Idaho, Utah, Nebraska, Oklahoma, and Missouri all gathered signatures through an initiative process to put expansion on the ballot, winning all five times. ${ }^{11-13}$ As it turned out, voters broadly comfortable with representation by ideologically conservative Republicans were also happy to break with orthodoxy on the point of health coverage for the poor. ${ }^{5,}{ }^{14}$ However, only four of the 12 holdout states have this option-Florida, Mississippi, South Dakota, and Wyoming. ${ }^{15}$ Even some states that have passed expansion have experienced delaying actions via conservative legislatures, ${ }^{16}$ with the most recent example being Missouri's legislature and governor refusing to budget for expansion. ${ }^{13}$

The last three remedies involve deploying federal power to either negotiate with or moot ideological opposition to expansion within states.
Remedy 3: Medicaid Waivers. One possible avenue is negotiation. Under Section 1115 of the Social Security Act, states can request the federal government waive certain requirements of the Medicaid program to evaluate experimental approaches that further the underlying goals of the program. Over the decades, waivers have provided critical experimental evidence to improve program performance. However, Section 1115 waivers can also be useful political tools that can defuse ideological conflict while advancing policy.

For example, Arizona's entire Medicaid program is based on a waiver that was a negotiated settlement that overcame ideological opposition to the state joining the program. ${ }^{4}$ Despite extreme financial pressure on counties responsible for providing health care to the poor, conservative state legislators refused to authorize funding to start a program for nearly a decade. In 1983, they finally compromised on creating a Medicaid program relying on managed care instead of traditional fee-forservice models to keep state finances in check. This reoriented the Medicaid program toward the goal of containing costs, as well as providing care for the poor, which defused ideological resistance while satisfying pro-expansion advocates.

Several states where conservative legislatures or governors blocked full expansion have embraced this logic, negotiating more ideologically appealing ways to expand coverage to lowincome adults rather than traditional Medicaid. In 2013, Arkansas became the first example, when Democratic Governor Mike Beebe and HHS agreed to use Medicaid money to purchase private exchange plans for individuals between 100 and $138 \%$ of the poverty line to satisfy objections of the conservative Republican-controlled legislature to Medicaid expansion. Michigan, Iowa, Indiana, New Hampshire, and Montana all developed waivers embracing some conservative priorities (usage of exchange plans, charging limited premiums or copays for certain populations) to overcome some ideological opposition. ${ }^{17}$

But there are limits to how much financial and ideological flexibility Section 1115 waivers can accomplish. The Obama administration, for example, was willing to make generous assumptions on fiscal neutrality to extend coverage to the uninsured but drew the line at out-of-pocket costs for individuals in households earning below the poverty line and work requirements. As evidenced by its categorical rejection of work requirements, The Biden Administration would likely have similar boundaries that will limit space for agreement on expansion via waiver, as its approach to Georgia has shown. ${ }^{18}$

Remedy 4: Pre-empt State Authority. Medicaid is a joint Federal-State program that allows state flexibility. However, the federal government can change the program unilaterally and force states to adhere to new standards or leave the program. In the $1980 \mathrm{~s}$, multiple expansions of Medicaid to children and mothers began as optional programs and later became mandatory coverage groups that compelled holdout states. The original ACA did make the expansion mandatory, 
but in National Federation of Independent Businesses $v$. Sebelius, the US Supreme Court held that the mandate was too coercive. ${ }^{19}$ Additionally, any pre-emption activities are likely to further fan the flames of conservative partisan opposition to expansion as government overreach. Therefore, largescale mandates for Medicaid changes are off the table, but smaller changes may still be feasible.

\section{Remedy 5: Create a Federally Run Alternative to Expansion.}

Finally, the federal government could create a workaround to cover people in states that choose not to expand. This option is perhaps the most viable - making the large assumption that Democrats control Congress and the White House. However, the challenge is to design a workaround that both covers individuals falling into the Medicaid gap in non-expansion states without jeopardizing gains made under the program. For example, simply extending ACA marketplace subsidies to those making less than the poverty line would close the Medicaid gap. However, marketplace coverage is inferior to Medicaid coverage on several metrics, most notably that it charges higher out-of-pocket costs and may feature narrower networks. ${ }^{20}$ Another potential workaround is creating a federally funded public option plan, which anyone living in a state that did not expand Medicaid and making under $138 \%$ of FPL could enroll free of charge. Biden proposed such a plan while running for President in 2020, although it appears that Democrats may attempt to go in a different direction. ${ }^{21}$ Both of these options would be eligible to be passed through reconciliation and therefore only require a simple majority in the US Senate. However, either one of these approaches effectively removes any incentive for states to expand Medicaid. They may even induce states to drop the expansion, since federal dollars will fund $100 \%$ of a public option or expansion of marketplace subsidies, while states still must contribute to Medicaid.

Greater financial aid from the Federal government may increase motivation to expand Medicaid for the 12 remaining holdout states. However, because the opposition is ideologically based, political rather than financial considerations will likely dominate expansion decisions over the next 2 years, limiting the effectiveness of ARPA's new incentives to expand Medicaid.

Acknowledgements: This material is based upon work supported in part by the Department of Veterans Affairs, Veterans Health Administration, Office of Research and Development, and the Center for Innovations in Quality, Effectiveness and Safety (CIN 13-413) and IIR 19-057 (Petersen PI).

Corresponding Author: Patrick N. O'Mahen, PhD; The Center for Innovations in Quality, Effectiveness and Safety (IQuESt) at the Michael E. DeBakey VA Medical Center, Houston, TX, USA (e-mail: omahen@bcm.edu).

\section{Declarations:}

Disclaimer: The views expressed in this article are those of the authors and do not necessarily represent those of the Veterans Health Administration or the US Government.

\section{REFERENCES}

1. Straw T, Lueck S, Katch H, Solomon J, Broaddus M, Lukens G. Health Provisions in American Rescue Plan Act Improve Access to Health Coverage During COVID Crisis.; 2021.

2. Rudowitz R, Corallo B, Garfield R. New Incentive for States to Adopt the ACA Medicaid Expansion: Implications for State Spending. https://www. kff.org/medicaid/issue-brief/new-incentive-for-states-to-adopt-the-acamedicaid-expansion-implications-for-state-spending/. Accessed April 23, 2021.

3. Levy H, Ayanian JZ, Buchmueller TC, Grimes DR, Ehrlich G. Macroeconomic Feedback Effects of Medicaid Expansion: Evidence from Michigan. $J$ Health Polit Policy Law. 2020;45(1):5-48. doi:https://doi.org/10.1215/ 03616878-7893555

4. Rose S. Financing Medicaid: Federalism and the Growth of America's Health Care Safety Net. Ann Arbor: University of Michigan Press; 2013.

5. O'Mahen P, Petersen L. State-Level Political Institutions Matter: The Balance of Powers Among Governors, Legislatures, and Direct Democracy Influences Medicaid Expansion Decisions. World Med Heal Policy. 2020;12(1):60-70. doi:https://doi.org/10.1002/wmh3.329

6. Hertel-Fernandez A, Skocpol T, Lynch D. Report on Health Reform Implementation: Business Association, Conservation Networks, and the Ongoing Republican War over Medicaid Expansions. J Heal Polit Policy, Law. 2016;41(2):239-286. doi:https://doi.org/10.1215/03616878-3476141

7. Beland D, Rocco P, Wadden A. Obamacare Wars: Federalism, State Politics, and the Affordable Care Act. Lawrence: University of Kansas Press; 2016.

8. Shepherd M. Gov. Mills reverses LePage push for Medicaid work requirements. Bangor Daily News. https://wgme.com/news/local/govmills-reverses-lepage-push-for-medicaid-work-requirements. Published January 22, 2019. Accessed July 9, 2021.

9. Fausset R, Goodnough A. Louisiana's New Governor Signs an Order to Expand Medicaid. New York Times. Accessed July 9, 2021.

10. Goodnough A. After Years of Trying, Virginia Finally Will Expand Medicaid. New York Times. https://www.nytimes.com/2018/05/30/ health/medicaid-expansion-virginia.html. Published May 30, 2018. Accessed July 9, 2021.

11. Kliff S. 4 States could expand Medicaid this year. That's a big deal. Vox. https://www.vox.com/policy-and-politics/2018/6/4/17426574/4states-could-expand-medicaid. Published 2018. Accessed July 5, 2018.

12. Forman C. Oklahoma voters approve Medicaid expansion at the ballot box. The Oklahoman. 2020.

13. Smith A. Medicaid Expansion Supporters Vow To Fight After Missouri Governor Scraps Voter-Approved Plan. KCUR (Kansas City National Public Radio outlet). https://www.kcur.org/health/2021-05-14/medicaid-expansion-supporters-vow-to-fight-after-missouri-governor-scraps-voterapproved-plan. Published May 21, 2021. Accessed July 9, 2021.

14. Rocco P, Keller AC, Kelly AS. State Politics and the Uneven Fate of Medicaid Expansion. Health Aff. 2020;39(3):01414. doi:https://doi.org/ 10.1377/hlthaff.2019.01414

15. National Conference of State Legislatures. Initiative and Referendum States. http://www.ncsl.org/research/elections-and-campaigns/chartof-the-initiative-states.aspx. Accessed May 7, 2018.

16. Singer PM, Nelson DB. Expansion by Ballot Initiative: Challenges and Future Directions in Health Policy. J Gen Intern Med. 2019;34(9):19131915. doi:https://doi.org/10.1007/s11606-019-05051-1

17. Musumeci M, Hinton E, Rudowitz R. Section 1115 Medicaid Expansion Waivers: a Look at Key Themes and State Specific Waiver Provisions.; 2017.

18. Alker J. Biden Administration Withdraws Medicaid Work Requirements Guidance and More. Say Ahhh!. 2021. https://ccf.georgetown.edu/ 2021/02/17/biden-administration-withdraws-medicaid-work-requirements-guidance-and-more/. Accessed July 9, 2021.

19. National Federation of Independent Business v. Sebelius. 567 US 519 (2012). doi:https://doi.org/10.1111/puar. 12079

20. O'Mahen PN, Petersen LA. Tradeoffs of Subsidizing ACA Marketplace Insurance for Adults below the Poverty Level. JAMA Health Forum 2(6) :e210871. doi:https://doi.org/10.1001/jamahealthforum.2021.0871.

21. Levitt L. Expanding Medicare to Adults at Age 60 Years-Medicare-forMore? Jama Heal Forum. 2021;2(5):1623. doi:https://doi.org/10.1001/ jamahealthforum.2021.1623

Publisher's Note: Springer Nature remains neutral with regard to jurisdictional claims in published maps and institutional affiliations. 